\title{
Mitos Cerita Sendhang Jetakwanger di Desa Jetakwanger Kecamatan Ngawen Kabupaten Blora
}

\author{
Endang Suryani ${ }^{\star 1}$ \\ ${ }^{1,2}$ Program Studi Sastra Jawa, Fakultas Bahasa dan Seni, Universitas Negeri Semarang
}

Info Artikel

Article History:

Diajukan January 9, 2019

Diterima June, 302019

Terbit June, 302019

\section{Kata kunci:}

mitos;

jenis mitos;

fungsi mitos

\begin{abstract}
Abstrak
Tujuan penelitian ini adalah untuk mengetahui makna cerita mitos Sendhang Jetakwanger, jenis dan fungsi mitos cerita Sendhang Jetakwanger bagi masyarakat pendukungnya. Penelitian ini menggunakan pendekatan kualitatif didukung dengan teori folklor dan mitos. Data penelitian yang digunakan berupa mitos cerita Sendhang Jetakwanger berupa data lisan dan tulis. Hasil penelitian menunjukkan bahwa jenis mitos Sendhang Jetakwanger, yaitu 1) mitos ruang dan waktu kosmos, 2) mitos asal-usul penciptaan, 3) mitos lingkungan. Fungsi mitos cerita Sendhang Jetakwanger, adalah 1) fungsi religius, 2) fungsi sosial budaya, 3) fungsi pendidikan, 4) fungsi ekonomi, fungsi pengembangan wisata daerah.
\end{abstract}

\begin{abstract}
The purpose of this research is to find out the meaning of the Sendhang Jetakwanger myth, the type and function of the Sendhang Jetakwanger myth to the supporting community. This study uses a qualitative approach supported by folklore theory and myth. The research data used in the form of the mythical story Sendhang Jetakwanger in the form of oral and written data. The results showed that the types of Sendhang Jetakwanger myths, namely 1) the space and time myth of the cosmos, 2) myths of the origin of creation, 3) environmental myths. The mythical functions of the Sendhang Jetakwanger story are: 1) religious function, b) socio-cultural function, c) educational function, d) economic function, regional tourism development function.
\end{abstract}

Published by UNNES. This is an open access

\section{PENDAHULUAN}

Jetakwanger merupakan salah satu desa yang masuk dalam Kecamatan Ngawen, Kabupaten Blora. Desa Jetakwanger terbagi menjadi 4 dukuh, yaitu dukuh Jetakwanger, dukuh Geneng, dukuh Pandan, dan dukuh Pojok. Mayoritas masyarakat desa Jetakwanger bekerja sebagai petani dan ada juga yang bekerja menjadi pegawai pemerintah. Masyarakat di desa Jetakwanger masih menjaga tradisi-tradisi yang ditinggalkan oleh leluhurnya pada zaman dahulu. Di desa Jetakwanger terdapat sebuah sendang yang konon ceritanya dibuat oleh orang-orang terdahulu yang sedang melakukan perjalanan jauh. Pada waktu itu para pengembara yang sedang kehausan disaat membabat hutan membuat galian seperti lubang (ledhokan). Kemudian di galian itu keluar sumber mata air, lalu mereka mengambil air dan

\section{E-mail:}

suryanie469@gmail.com

Alamat: Gedung B-8 Fakultas Bahasa dan Seni

Universitas Negeri Semarang

Kampus Sekaran, Gunungpati, Semarang 50229 meminumnya. Dari ledhokan itulah kemudian dijadikan masyarakat sekitar sebagai sumur / sendhang dan dinamakan sebagai sendang Jetakwanger karena letaknya di tengah desa Jetakwanger.

Banyak masyarakat yang mempercayai mitos yang ada di sendang Jetakwanger. Misalnya jika ada orang yang sakit diambilkan air dari sendang itu maka akan sembuh. Orang yang sedang hamil sering mandi di sendang tersebut, konon katanya anaknya akan memiliki kulit putih. Jika bertepatan pada hari Jumat, orang yang mandi di sendang akan awet muda. Mitos-mitos seperti inilah yang tumbuh berkembang di masyarakat.

Mitos merupakan sastra lisan yang diturunkan para leluhur terdahulu, mitos erat kaitannya dengan dunia gaib, dan mitos dianggap kejadian yang benar- benar ada serta merupakan sesuatu yang sangat sakral. Menurut Lukens (Danandjaja 2002:172) mitos merupakan sesuatu yang diyakini bangsa atau masyarakat tertentu yang pada intinya menghadirkan kekuatan-kekuatan supranatural. Begitu luasnya perkembangan mitos sehingga setiap desa, kota, provinsi, maupun negara mempunyai cerita mitos sendiri-sendiri. Apalagi di daerah

DOI 10.15294/sutasoma.v7i1.33383 
Jawa mitos sangat dipercayai oleh masyarakat, orang jawa sangat dekat dengan mitos. Mitos mempunyai kekuatan supranatural berbabau mistis dan religius. Seperti yang terjadi di sendang Jetakwanger, saat bulan Sura (Muhharam) banyak yang datang ke sendang ini dengan tujuan tertentu untuk lancar rejeki,diberikan kesehatan, awet muda, gampang jodoh dan sebagainya. Pengunjung tidak hanya dari masyarakat setempat, tetapi juga dari luar desa ataupun luar kota. Zeffry (1998:16-17) membagi mitos menjadi 3 jenis, yaitu, a) mitos ruang dan waktu kosmos; b) mitos asal usul penciptaan; c) mitos lingkungan (ekologi), mitos ini berkaitan dengan kepercayaan masyarakat tentang sebuah tempat yang dianggap suci dan keramat. Cerita mitos juga memiliki beberapa fungsi, yaitu a) fungsi pendidikan; b) fungsi ini sosial budaya; c) fungsi pendidikan; d) fungsi sosial William R. Bascom (Danandjaja 2002:19).

\section{METODE}

Metode penelitian ini menggunakan metode deskriptif kualitatif, yaitu pendekatan dengan cara melihat objek pengkajian sebagai suatu sistem acuan, dengan kata lain objek kajian dilihat sebagai satuan yang terdiri atas unsur yang saling terkait. Lokasi penelitian ini di dukuh Jetakwanger RT01/RW02, desa Jetakwanger, Kecamatan Ngawen, Kabupaten Blora. Sasaran penelitian adalah cerita mitos sendang Jetakwanger. Data penelitian ini diambil dari hasil wawancara informan yaitu masyarakat setempat desa Jetakwanger, Kecamatan Ngawen, Kabupaten Blora. Sumber data dalam penelitian ini yaitu sumber data lisan dan sumber data non lisan/ tulis. Sumber data lisan diperoleh dari wawancara berupa tuturan, ujaran, sumber data tulis berupa dokumen-dokumen dari balai desa Jetakwanger.

Teknik pengumpulan data dalam penelitian ini menggunakan teknik observasi, wawancara, studi pustaka, dan teknik dokumentasi (Rahman 1993:31). Teknik observasi (pengamatan) digunakan untuk mengetahui data yang berhubungan dengan mitos Sendang Jetakwanger, sikap masyarakat dan perilaku interaksi sosial antara anggota masyarakat. Teknik wawancara adalah sebuah dialog yang dilakukan oleh pewawancara untuk memperoleh informasi dari narasumber. Dalam memilih informan haruslah informan yang dianggap menguasai dan dapat dipercaya untuk menjadi sumber data yang jelas. Informan yang dipilih adalah sesepuh desa atau perangkat desa karena secara umum mereka yang mengetahui secara pasti tentang mitos cerita Sendang Jetakwanger. Studi Pustaka merupakan cara pengumpulan data dengan mengambil peninggalan tertulis, seperti arsip-arsip dan termasuk juga buku-buku tentang pendapat teori, dalil-dalil, atau hukum-hukum dan lain-lain yang berhubungan dengan masalah penelitian (Rahman 1993:31). Teknik dokumentasi dalam penelitian ini berupa dokumen (foto) dan informasi dari masyarakat yang berhubungan dengan objek penelitian.

Teknik analisis data menggunakan teknik kajian isi/ content analysis. Metode content analysis merupakan analisis ilmiah tentang isi pesan suatu komunikasi. Disini penelitian menganalisis, menguraikan data-data yang telah terkumpul kemudian mengolahnya, mentelaah, mentafsirkannya, untuk memperoleh hasil dari rumusan masalah yaitu mendiskripsikan jenis mitos cerita sendang dan fungsinya bagi masyarakat pendukungnya.

\section{HASIL DAN PEMBAHASAN}

Desa Jetakwanger adalah desa di kecamatan Ngawen, Blora, Jawa Tengah, Indonesia. Jetakwanger merupakan desa yang jauh dari perkotaan. Desa Jetakwanger secara geografis berbatasan langsung dengan Kecamatan Banjarejo, sehingga menyebabkan aktivitas ekonomi juga lebih banyak dilakukan di Kecamatan Banjarejo. Hal ini dikarenakan akses ke Kecamatan Ngawen yang susah, harus melewati sungai Lusi tetapi saat ini sudah bisa dilalui karena sudah ada jembatan penghubung di desa Karangtengah. Desa Jetakwanger sebetulnya memiliki potensi untuk berkembang karena posisinya yang berada di pinggir hutan jati, sehingga bisa dijadikan mitra bagi Perhutani untuk mengembangkan kawasan hutan jati yang menjadi ikon kabupaten Blora. Saat ini masyarakat di desa Jetakwanger banyak yang menanam pohon jati di sekitar lingkungan rumah mereka ataupun di daerah tegalan.

Pemuda di desa Jetakwanger umumnya lebih condong bekerja sebagai TNItetapi ada pula yang bekerja di sektor pemerintahan dan swasta atau bekerja di bidang industrial seperti di kota Semarang, Jakarta dan Surabaya. Tetapi masyarakat di desa Jetakwanger mayoritas bekerja sebagai petani. Masyarakat desa umumnya memiliki tanah sendiri yang nanti hasil panennyadigunakan untuk kelangsungan hidup.

\section{Makna Mitos dibalik Cerita}

Mitos mengandung keinginan bawah sadar manusia untuk mengungkapkan, menerangkan, serta menjawab berbagai gejala dan peristiwa yang terjadi disekelilingnya. Mitos dibuat untuk kepentingan manusia yang dalam perkembangannya kemudian membentuk tradisi yang berlaku dan bahkan kadang- kadang perlu diberlakukan. Ritual merupakan gejala umum yang didasari oleh asas keagamaan. Dalam arti bahwa manusia mempunyai kewajiban untuk mengembalikan pemberian dari Tuhan dalam bentuk ritual pengorbanan dan pelayanan (Zeffry 1998:28-103).

"Dadi jenenge Jetakwanger iku tembung saka araara bothak dinggo tenger, dadi mbesuk nek dadi desa dadi desa Jetakwanger merga ara-ara bothak iku tho sing nggoni blok umahe sujak kui ndek anu kelurahan kawak kuwi, dadi ara-ara bothak dingo tenger. Bibit bibit pisanane iki saka desa pojok kui pojok an, terus tegalan kui di nggo tenger tegalan ara ara bothak (mbah Sungkono 80 tahun).

Terjemahan dari perkataan mbah Sungkono di atas :

Jadi namanya Jetakwanger itu di ambil dari kata ara-ara bothak dingo tenger (halaman yang luas / padang rerumputan dipakai untuk beristirahat), jadi nanti kalau jadi desa jadi desa Jetakwanger. 
Karna itulah tadi ara-ara bothak yang ditempati rumahnya mbah sujak itu dulu kelurahan lama, ara- ara dingo tenger asal mulanya dari desa Pojok, tegalan ( semacam sawah tapi luas) yang kemudian di buat istirahat.

Asal-usul cerita sendang Jetakwanger ada beberapa pengembara yang masuk ke hutan atau dalam istilah Jawaadalah wong babati alas. kemudian pengembara tersebut merasa haus dan ingin minum, tapi tidak ada aliran air atau sumber mata air. Kemudian mereka menggali tanah untuk membuat lubang lalu keluarlah air dari lubang itu. Dahulu belum ada desa di sana, sekarang sudah ada desa dan desa itu diberi nama desa Jetakwanger. Warga disana akhirnya membangun lubang itu lalu menatanya dan kemudian dinamakan sendang Jetakwanger. Semua aktivitas warga sangat berganutng pada sendang itu, mulai dari untuk minum, irigasi memberi minum hewan peliharaan, masak dan sebagainya. Air sumur itu tidak habis-habis walaupun diambil terus menerus-menerus pagi siang sore.

"Sendhang Jetakwanger kuwi kuwi patilasan saking jaman kae, lha saking senenge masyarakat kui mau di bangunlah sendhang. Sing tunggu kana kuwi mantan jogged jenenge mbah Sulastri pindahan saka Bangeran. Mula yen sedekah bumi kudu wajib nanggap jogged (mbah sungkono 80 tahun).

Terjemahan :

"Sendhang Jetakwanger itu warisan dari orang jaman dahulu, karena sangat senang dengan adanya sumber air tersebut dibangunlah sendhang. Yang menunggui sendhang disana adalah mantan jogged, namanya mbah Sulastri dia pindahan dari desa Bangeran. Oleh karena itu jika bersih desa diwajibkan hiburannya jogged ( mbah Sungkono 80 tahun).

Banyak masyarakat dari luar desa dan luar kota yang hampir setiap malam Jumat datang ke sendnag Jetakwanger dengan berbagai tujuan. Masyarakat yang datang ke sendang Jetakwanger bertujuan agar lancar rejekinya, jodoh, diberikan kesehatan, penglarisan dan lain-lain. Apalagi pada saat bulan Muharram banyak warga yang datang ke sendang Jetakwanger pada waktu malam hari. Dengan adanya kepercayaan yang telah hidup di tengah masyarakat, kemudian muncullah mitos yang berkembang di sendang Jetakwanger. Adapun mitos yang yaitu:

- Orang yang sering mandi di sendhang itu akan awet muda, Maksudnya seseorang yang sering mandi tubuhnya atau badannya sudah pasti akan terlihat lebih bersih dan terlihat muda

- Orang yang sakit jika di ambilkan air dari sendhang itu akan sembuh

Maksudnya yang memberikan segala macam penyakit itu adalah sang kuasa, lewat air itu atau lantaran air itu diberi kesembuhan sang kuasa.

- Orang yang hamil jika sering mandi disitu, bayinya akan lahir putih.
Maksudnya dikatakan putih ini yaitu bersih hatinya, bukan kulitnya.

- Dilarang bermain di area Sendhang, nanti bahaya dapat gangguan

Maksudnya jika bermain disitu nanti jatuh, soalnya licin diarea sendhang dan ditakutkan nanti jatuh kedalam sumurnya

- Tidak boleh memasukan sesuatu ke dalam sumur, nanti penunggunya marah

Maksudnya jika yang dimasukan kotoran / sampah akan mencemari air yang ada di dalam sumur itu. Jadi nanti warga yang marah. Soalnya air itu dipakai untuk segala aktivitas warga

\section{Jenis Mitos}

Zeffry (1998:16-17) membagi mitos menjadi 3 jenis, yaitu, a) mitos ruang dan waktu kosmos. Mitos jenis ini berkaitan dengan sistem penanggalan suatu kelompok masyarakat untuk melakukan ritual atau perayaan yang sudah menjadi tradisi; b) mitos asal usul penciptaan. Mitos ini bersifat universal dan klasik; c) mitos lingkungan (ekologi). Mitos ini berkaitan dengan kepercayaan masyarakat tentang sebuah tempat yang dianggap suci dan keramat. Dalam mitos cerita Sendhang Jetakwanger terdapat beberapa jenis mitos yang sesuai dengan pernyataan Zeffry. Jenis mitos dari cerita sendang keramat tersebut yang paling mendominasi adalah pada jenis yang ketiga, yaitu adanya mitos lingkungan yang berhubungan dengan kepercayaan sekelompok masyarakat terhadap suatu tempat yang dianggap suci dan keramat.

Berikut jenis mitos cerita sendhang Jetakwanger. Mitos ruang dan waktu kosmos. Mitos jenis ini berkaitan dengan sistem penanggalan suatu kelompok masyarakat untuk melakukan ritual atau perayaan yang sudah menjadi tradisi misalnya saat perayaan atau acara bersih desa masyarakat berkumpul membawa jajan wujud syukur mereka atas hasil bumi dalam istilah jawa yaitu kondangan. Biasanya jajan berupa pasung, bugis, pisang, tape dan jajanan lainnya. Setelah kondangan ada hiburan tayub. Mitos asal penciptaan. Mitos ini bersifat universal dan klasik. Karena sendhang ini sudah bersifat umum bukan rahasia warga ataupun masyarakat sudah mengetahui hal ini. Klasik karena terbentuk semua berawal dari cerita jaman dahulu. Mitos lingkungan (ekologi). Mitos ini berkaitan dengan kepercayaan masyarakat tentang sebuah tempat yang dianggap suci dan keramat. Kepercayaan masyarakat tersebut telah menimbulkan bentuk peraturan atau larangan yang mutlak. Adapun larangan -larangan yaitu contohnya a) Dilarang bermain di area Sendhang, nanti bahaya dapat gangguan b) tidak boleh berbicara sembarang jika berada didalam sendhang c) tidak boleh memasukan sesuatu ke dalam sumur.

\section{Fungsi Mitos}

Mitos bukanlah semacam reportase peristiwa-peristiwa terdahulu yang berhubungan dengan dunia ajaib, melainkan memberikan pedoman hidup bagi kebijaksanaan penganutnya atau masyarakat pendukungnya. 
Mitos juga memiliki berbagai macam fungsi, misalnya fungsi religious, sosial budaya, pendidikan, ekonomi, Fungsi bidang sosial budaya Sendhang Jetakwanger adalah sebagai pengikat tali silaturahmi antarwarga atau sarana menciptakan kerukunan antarwarga. Masyarakat bergotong-royong memperbaiki sendang serta melakukan upacara keagamaan. Selain itu, dengan adanya pembentukan panitia pembangunan atau kepengurusan berfungsi untuk menciptakan rasa solidaritas terhadap sesama anggota. Para anggota tim tersebut juga dapat menyalurkan ide-ide yang berhubungan dengan tugas yang dikerjakannya, sehingga mereka dapat bekerjasama mewujudkan ide yang mereka punya. Salah satu contoh saat acara bersih desa atau sedekah bumi. Fungsi bidang pendidikan adalah memberi pengetahuan pada remaja, anak -anak dan masyarakat akan adanya tradisi adat istiadat jawa. Fungsi religious dalam cerita mitos Sendhang Jetakwanger ini adalah dimana semua makhluk hidup itu ciptaan sang Pencipta sang Kuasa kita diharuskan percaya bahwa hal -hal gaib itu benar adanya. Fungsi dalam bidang ekonomi adalah dengan adanya sendhang ini aktivitas warga Jetakwanger dalam pokok mata pencarian yaitu petani bisa tercukupi untuk irigari air karena warga mengambil air untuk tanamannya, dengan adanya air tamanan tumbuh subur dan bisa panen.

\section{SIMPULAN}

Dari hasil analisis penelitian dapat disimpulkan suatu mitos mempunyai makna atau isi tersendiri bagi masyarakat. Di sendhang Jetakwanger ada beberapa mitos yang berkembang Orang hamil yang mandi di sendhang itu kelak bayi yang dilahirkan akan lahir putih. Maksudnya ini bukan bayi yang berkulit putih melainkan setiap bayi yang lahir hatinya akan putih dan bersih. Orang yang sakit jika di ambilkan air dari sendhang itu akan sembuh. Maksudnya yang memberikan segala macam penyakit itu adalah sang kuasa, lewat air itu atau lantaran air itu diberi kesembuhan sang kuasa. Jenis mitos cerita sendhang Jetakwanger adalah Mitos ruang dan waktu kosmos. Mitos jenis ini berkaitan dengan sistem penanggalan suatu kelompok masyarakat untuk melakukan ritual atau perayaan yang sudah menjadi tradisi misalnya saat perayaan atau acara bersih desa masyarakat berkumpul membawa jajan wujud syukur mereka atas hasil bumi dalam istilah jawa yaitu kondangan. Biasanya jajan berupa pasung, bugis, pisang, tape dan jajanan lainnya. Setelah kondangan ada hiburan tayub. Mitos asal penciptaan. Mitos ini bersifat universal dan klasik. Karena sendhang ini sudah bersifat umum bukan rahasia warga ataupun masyarakat sudah mengetahui hal ini. Klasik karena terbentuk semua berawal dari cerita jaman dahulu. Mitos lingkungan (ekologi). Mitos ini berkaitan dengan kepercayaan masyarakat tentang sebuah tempat yang dianggap suci dan keramat. Kepercayaan masyarakat tersebut telah menimbulkan bentuk peraturan atau larangan yang mutlak.

Fungsi mitos cerita Sendhang Jetakwanger bagi masyarakat Fungsi bidang sosial budaya Sendhang Jetakwanger adalah sebagai pengikat tali silaturahmi antarwarga atau sarana menciptakan kerukunan antarwarga. Fungsi bidang pendidikan adalah memberi pengetahuan pada remaja, anak -anak dan masyarakat akan adanya tradisi adat istiadat jawa. Fungsi religious dalam cerita mitos Sendhang Jetakwanger ini adalah dimana semua makhluk hidup itu ciptaan sang Pencipta sang Kuasa kita diharuskan percaya bahwa hal -hal gaib itu benar adanya. Fungsi dalam bidang ekonomi yaitu sendang Jetakwanger digunakan warga untuk mengairi persawahan yang pada akhirnya membantu perekonomian warga. Fungsi pengembangan wisata daerah. Fungsi ini merupakan fungsi baru atau temuan dalam penelitian mitos cerita Sendang Jetakwanger. Lokasi ini dapat dikembangkan dan dijadikan wahana wisata jika warga masyarakat mendukung. Saran yang dapat diberikan berdasarkan hasil penelitian ini adalah mitos cerita Sendhang Jetakwanger dapat dijadikan acuan untuk penelitian selanjutnya. Selain itu, mitos cerita Sendhang Jetakwanger hendaknya dilestarikan, karena mitos merupakan aset budaya yang harus dijaga.

\section{DAFTAR PUSTAKA}

Amin, dkk. 2013. Cerita Rakyat Penamaan Desa di Kerinci: Kategori dan Fungsi Sosial Teks. Jurnal Bhasa, Sastra dan Pembelajaran Volume1 Nomor 1. Padang: Universitas Negeri Padang.

Arikunto, Suharsini. 2010. Prosedur Penelitian Suatu Pendekatan Praktek. Jakarta: Rineka Cipta.

Arneti. Asal-Usul Penamaan Nama-nama Jorong di Kanagarian Batukambiang Kecamatan Ampek Nagari Kabupaten Agam. Skripsi. Universitas Negeri Padang, Sumatra Barat.

Asosiasi Tradisi Lisan. 2015. Metode Kajian Tradisi Lisan. Jakarta: yayasan putera obor.

Danandjaja, James. 2002. Folklor Indonesia. Jakarta : Pustaka Utama Grafiti.

Endraswara, Suwardi. 2005. Tradisi Lisan Jawa. Yogyakarta : Narasi.

Sudikan, Setya Yuwana. 2001. Metode Penelitian Sastra Lisan. Surabaya : Citra Wacana

Purwadi. 2009. Folklor Jawa. Yogyakarta : Pura Pustaka. 